\title{
Bantuan-bantuan yang Dibutuhkan untuk Mengentaskan Kemiskinan di Indonesia
}

\author{
Oleh : Bachruddin
}

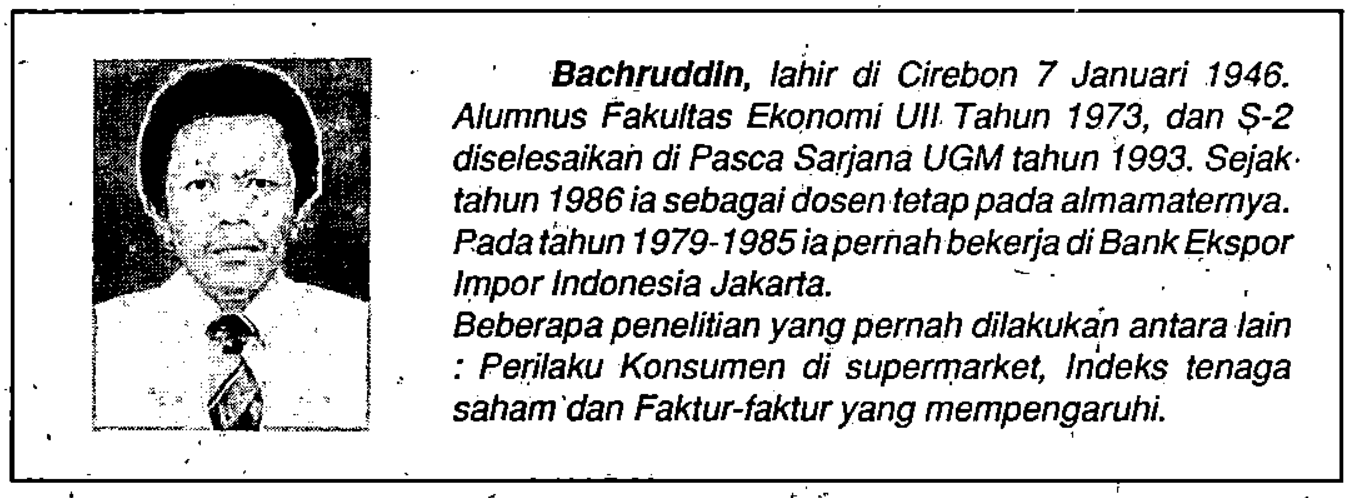

Pendahuluan

Dalam membicarakan masalah kemiskinan biasanya dibenak kita senantiasa dilintasi oleh suatu pertanyaan yaitu, apakah kemiskinan itu merupakan suratan takdir (nasib) ataukah merupakan produk samping dari șuatu kebijaksanaan.

Kàlau kemiskinan merupakan nasib yang. ditimpakan kepada sebagian umat manusia, sejak kapan hal itu terjadi dan apakah nasib mereka bisa berubah? Berdasarkan pengalaman sejarah, nampaknya kemiskinan itu melekat sepanjang peradabanmanusia. Kemiskinan dapat terjadi dimana-mana, baik 'di masyarakat yang telah maju maupun di masyarakat yang belum maju. Yang paling menonjol dan sangat memprihatinkan adalah yang terjadi di negara-negara berkembang dan yang masih terbelakang. Betapa tidak, melalui berbagai media masa dewasa ini kita dapat mengetahui adanya kelompok-kelompok umat manusia yang tengah ditimpa kemelaratan dan bahkán kelaparan. Jumlah mereka masih cukup banyak dan tersebar di seluruh belahan dunia ini, yang hidupnya sangat tergantung adanya bantuan dari pihak lain.

Betulkan nasib orang miskin sulit dirubah karena mereka berada dalam suatu lingkaran setan, sebágaimana dinyatakan oleh Gunnar Myrdal atau Ragnar Nurkse? Orangmiskirjpada pokoknya digambarkan sebagai kelompok manusia yang karena kondisinya sedemikian rupa sehingga tetap miskin. Mereka kekurangan pangan sehingga kemampuan bekerjanya rendah, usaha tani kecil karena daya dukung alam 
terbatas dan jumiah mereka semakin bertambah, yang mengakibatkan mereka. tetap kekurangan. Potret kehidupan seperti ini memang banyak dijumpai di negaranegara berkembang yang sebagian besar hidupnya tergantung pada sektor pertanian yang tradisional dengan jumlah penduduk yang padat.

Sementara itu, kalau kemiskinan dianggapsebagai produk sampingdari suatu kebijaksanaan, mengapa jadi demikian dan siapa yang bertanggung jawab? Faktorfaktor yang menunjukkan bahwa' kemiskinan itu produk dari kebijaksanaan adalah adanya ketimpangan yang sangat. menyolok antara kelompok manusia yang hidupnya serba kecukupan dan kelompok manusia yang hidupnya sangat kekurangan di dalam suatu negara. Keadaan demikian terutama banyak dijumpai di dalam masyarakat yang sedang bergelut dengan upaya-upaya pembangunan. Atau dalam lingkup global, kita menyaksikan adanya kesenjangan tingkat kehidupan antara, negara-negaramaju dannegara-negara yang masih berkembang dan terbelakang.

Telah cukupdisadari oleh para analis pembangunan bahwa, peletakan kebijaksanaan yang tidak tepat dapat dianggap sebagai biang keladi terjadinya kesenjangan-kesenjangan sosial. Oleh karenanya, dalam berbagai kesempatan atau forum telah banyak muncul semacam protes dari kelompok negara-negara berkembang, akan perlunya suatu perombakan tatanan dunia yang lebih adil. Kemiskinan dan keterbelakangan yang dialami oleh negaranegara berkembang adalah cerminan dari tatanan ekonomi dunia yang lebih banyak menguntungkan negara-negara maju. Dalam lingkup yang lebih sempit, temyata juga kebijaksanaan nasional yang diterapkan oleh negara-negara berkembang sendiri banyak yang kurang tepat. Adalah tidak heran kalau kita menyaksikan berbagai konflik dan pergolakan sosial yang masih berkecamuk di negara-negara yang masih mencari bentuk yang tepat dalam kebijaksanaan pëmbangunan.

Bagi kita, bangsa Indonesia, kiranya patutbersyukurtelah dapatmelewati dengan selamat tahapan panjang pertama pembangunan nasional yang berakhir 31 Maret 1994. Tanpa menutup mata akan adanyakekurangan-kekurangan yang masih dirasakan di sana sini, ternyata bahwa selama PJPT I telah mencatat sejumlah keberhasilan-keberhasilan. Salah satu aspeknya adalah penurunan jumlah penduduk miskin. kalau pada tahun 1976 secara absolut masih berjumlah 54,2 juta (= $40,1 \%$ dari jumlah penduduk) maka pada tahun 1990 turun menjadi 27,0 juta jiwa (= $15 \%$ dari jumlah penduduk).

Dalam rangka untuk mengurangi jumlah penduduk miskin secara lebih cepat maka mulai 1 April 1994 (awal PJPT I), pemerintah meluncurkan suatu program khusus berupa Inpres Desa Tertinggal (IDT). Ada dua hal kiranya yang dapat disimak dari program khusus ini. Pertama, nampaknya pemerintah lebih bersunggúhsungguh dalam menanggulangi masalah kemiskinan melalui suatu kebijaksanaan yang langsung ditujukan kepada sasarannya yaitu desa-desa miskin yang bersangkutan. Kedua, adanya IDT dapat diartikan semacam upaya koreksi atas kebijaksanaankebijaksanaan pembangunan yang telah diterapkan selama ini, yang nampaknya belum banyak dinikmati oleh kelompok masyarakat yang disebut miskin/tertinggal. 
Upaya pengentasan kemiskinan tentunya bukan pekerjaan yang mudah karena menyangkut berbagai masalah yang komplek. Dalam kaitan ini diperlukan analisis dan strategi baik secara mikro maupun makro yang saling menunjang dan berkesinambungan. Kita tentunya memahami bahwa IDT bukanlah satusatunya jalan yang berdiri sendiri. Guna suksesnya upaya pengentasan kemiskinan maka seiring dengan diterapkannya IDT, perlu dipikirkan kebijaksanaankebijaksanaan tertentu yang lebihmendasar baik secara mikro dan makro. Selain itu, peran serta dari semua pihak untuk membantu program ini patut pula dipersiapkan sehingga merupakan suatu kesatuan sistem yang komplementer.

\section{Sosok Kemiskinan}

Kemiskinan adalah situasi serba kekurangan yang terjadi bukan karena dikehendaki si miskin, melainkan karena tidak dapat dihindari dengan kekuatan yang ada padanya (Panduan Program IDT).

Sementara itu keadan kemiskinan umumnya diukur dengan tingkat pendapatan, yang pada dasamya dapat dibedakan antara kemiskinan absolut dan kemiskinan relatif.

Seseorang dianggap miskin secara absolut bila tingkat pendapatannya di bawah garis kemiskinan sehingga tidak cukup untuk memenuhi kebutuhan hidup minimum. Sedangkan kemiskinan relatif adalah keadaan perbandingan antara kelompok masyarakat yang sudah di atas. garis kemiskinan tetapi lebih miskin dibanding kelompok masyarakat lain.

Berpijak dari pengertian dimaksud maka kemiskinan dapat dianggap sebagai produk dari kebijaksanaan pembangunan yang menghasilkan adanya ketimpangan dalam distribusi pendapatan.

Apabila ditinjau dari sifat-sifatnya, kemiskinan dapat dibedakan dalam tiga pengertian yaitu, kemiskinan natural, kemiskinan struktural dan kemiskinan kultural.

\section{Kemiskinan Natural}

Kemiskinan natúral adalah keadaan di mana mereka miskin karena tidak memiliki sumber daya yang memadai sehingga tidak dapat ikut aktif dalam pembangunan, atau mendapat inbalan yang amat rendah.

Sosok kemiskinan natural seperti ini dapat dijumpai pada kelompok masyarakat berpenghasilan rendah baịk sebagai buruh tani, pekerja kasar, nelayan kećil, dan lainlain yang biasanya berada diperkampungan hunian yang kumuh. Jumlah golongan ini cukup banyak, baik di kota-kota maupun di pedesaan.

Kemiskinan natural biasanya muncul di negara-negara yang baru atau sedang membangun. Kebijaksanaan pembangunan yang diterapkan belum dapat menciptakan adanya pemerataan dalam kesempatan dan pemilikan sumber-sumber ekonomi. Pada gilirannya mengakibatkan perolehan pendapatan yang tidak seimbang antara golongan masyarakat tertentu dengan lainnya.

\section{Kemiskinan Struktural}

Kemiskinan Struktural pada dasarnya keadaan kemiskinan yang disebabkan oleh hasil pembangunan yang belum seimbang. Ketidak seimbangan ini dapat dijumpai baik antar sektor 
pembangunan, antar daerah atau antar golongan/pelaku ekonomi.

Kebijaksanaan pembangunan yang hanya tertuju pada daerah-daerah yang maju, dapat menimbulkan ketimpangan kemajuan antar daerah. Pada daerah-daerah tertentu di luar Jawa tampak masih tertinggal. Di Kalimantan Tengahmisalnya, $56,54 \%$ merupakan desa miskin karena peimbangunan prasaraná yang minim.

Di sisi lain, adanya kebijaksanaan alokasi sumber yang timpang dapat menimbulkan adanyagolongankecilpelaku ekonomi yang maju (monopoli), sementara sebagian besargolongan lainnya yang masih gurem.

Kemiskinan struktural juga dapat muncul karena ketidak seimbangan dalam memperoleh kesempatan menikmati gerak pembangunan. Dalam hal ini kita jumpai adanya sebagian masyarakat yang berpendidikan tinggi dan sebagian besar masyarakat yang masih berpendidikan rendah.

\section{Kemiskinan Kultural}

Kemiskinan kultural menunjuk pada perilaku masyarakat yang memiliki kebiasaan, kebudayaan atau gaya hidup yang sulit untuk dirubah.

Keadaan kemiskinan kultural dapat dijumpai misalnya pada kehidupan masyarakat yang masih terisolir atau sukusuku terasing. Mereka kebanyakan mengandalkan mata pencahariannya dengan bercocok tanam, di mana tanah menjadi tumpuan hidupnya.

Di samping itu, kemiskinan kultural juga ditemui pada kelompok masyarakat yang hidupnya, menggarap ladang secara berpindah-pindah yang merupakan suatu kebiasaan mereka. Hal ini mereka lakukan karena kondisi tanah yang tidak subur. Bentuk kehidupan seperti ini misalnya dijumpai pada masyarakat suku Dayak di Kalimantan. Mereka punya ikatan yang kuat terhadap tanah sebagai sumber kehidupan dan sulit untuk beranjak dari kebiasaan dan sikap seperti itu.

\section{Identifikasi Faktor-faktor Penyebab Kemiskinan}

Agar supaya upaya pengentasan kemiskinan dapat mengenai sasaran dan berhasil dengan baik maka lebih dahulu perlu diidentifikasi secara jelas faktor-faktor yang diduga. menyebabkan timbulnya kemiskinan: Ini bukan pekerjaan mudah karena diperlukan suatu sikap yang terbuka dan hati yang jemih dari semua pihak yang berasa bertanggung jawab terhadap kemiskinan. Terutama bagi para pengambil keputusan/kebijaksanaan pembangunan, dibutuhkan adanya semacam self-critics atas apa-apa yang telah dilakukan selama ini. Sebab, sebagaimana telah disinggung di muka bahwa kemiskinan dapat terjadi sebagai produk dari peletakan kebijaksanaan pembangunan yang kurang tepat yang memunculkan kesenjangankesenjangan.

Faktor-faktor penyebab kemiskinan tentunya cukup kompleks, yang pada dasamya dapat diklasifikasikan menjadi faktor-faktor makro dan faktor-faktor mikro. Berikut ini dicoba untuk mengidentifikasi beberapa fakior makro dan mikro yang mungkin dirasakan berpengaruh lerhadap limbulnya kemiskinan. 


\section{Faktor-faktor Makro}

Kebijakan pembangunan yang mengejar target pertumbuhan agregat

Pada tahap-tahapawal pembangunan dimulai, dapat dipahami kalau titik sentral dari pembangunan nasional adalah tercapainya pertumbuhan yang cukuplayak secara agregat. Namun demikian, kita pun sudah semakin sadar bahwa hasil dari kebijaksaniaan tersebut banyak yang tidak menyentuh golongan miskin, karena gagalnya hipotesis "tricle-down-effect". Artinya bahwa disamping sejumlah sukses yang dicapai dalam proses pembangunan selama ini, mencuat pula kesenjangankesenjangan sosial-ekonomi yang kurang/ tidak terkontrol. Salah satu pihak yang menjadi korban adalah mereka yang tergolong masih tertinggal/miskin.

\section{Pembangunan yang kurang menekankan pada pembangunan wilayah}

Barangkali karena pertimbangan keterbatasan sumberdana dan daya, selama ini dirasakan bahwa arah kegiatan pembangunan lebih ditujukan kepada daerah-daerah yang telah maju. Dapat dilihat akibatnya bahwa bagi wilayah yang telah maju menjadi semakin maju sementara itu bagi wilayah lainnya kurang mendapat perhatian dan tidak dapat menikmati pembangunan secara layak. Unsur sentralisasi lebih menonjol dari pada desentralisasi/kewilayahan, yang menimbulkan dampak kurangnya otonomi dan kreativitas daerah untuk menggali potensinya. Kesenjangan daerah/wilayah seperti yang kita lihat dewasa ini akan tetap tidak terpecahkan kalau unsurkewilayahan kurang mendapat tekanan dalam kebijaksanaan pembangunan.

Adanya praktek-praktek monopolistik dan monopsonistik

Kekurang-mampuan dari pihak pengelola pembangunan untuk melakukan kontrol atas proses pembangunan secara makro dapat menimbulkan adanya praktekpraktek monopoli/monopsoni oleh segolongan pelaku ekonomi atas assets nasional. Keadaan seperti ini telah pula terjadi di dalam perjalanan pembangunan selama PJPT I di Indonesia, yang sebagian besar dari kita telah mengetahui dan merasakan. Adanya praktek-praktek monopoli/monopsoni telah menimbulkan ketidak seimbangan daläm kekuatan pasar sehingga menciptakan kondisi perekonomian yang tidak efisien. Selain itu sebagian besar pelaku-pelaku ekonomi yang lemah kurang memperoleh peluang. Kemiskinan merupakan akibat lebih lanjut dari proses ini, yang muncul dari golongan ekonomi lemah yang semakin terpojok.

Pola operasi perbankan yang kápitalistik

Keberadaan lembaga keuangan perbankan menempati posisi yang cukup menentukan dalam alokasi dana-dana pembangunan. Di samping berfungsi menghimpun dana-dana dari masyarakat, perbankan memegang peranan kunci dalam penyaluran dana dalam bentuk perkreditan. Walaupun kebijaksanaan dasar telah diarahkan agar perbankan mampu mengemban misi sebagai agen pembangunan namun dalam praktek operasionalnya nampak kurang terkontrol. Hal ini dapat dilihat dari alokasi dana perkreditan yang lebih banyak dinikmati oleh golongan ekonomi kuat, sementara 
porsi perkreditan bagi golongan ekonomi lemah masih sangat sedikit. Sebagai akibat dari kebijaksanaan operasi perbankan yang bersifat "kapitalistik" (mengutamakan golongan ekonomi kuat) tersebut maka sebagian besar kalangan ekonomi lemah masih tertinggal jauh di belakang.

\section{Pengelolaan kota besar yang tidak memihak kepada golongan lemah}

Kehidupan kotakhususnyakota-kota besar nampaknya lebih diperuntukan bagi warga dari kalangan atas yang mendapat fasilitas-fasilitas yang istimewa. Sebaliknya tidak ada ruang dan kesempatan bagi mereka yang lemah/miskin. Tidak jarang kita saksikan adanya penggusuran-penggusuran terhadap pemukiman-pemukiman rakyat kecil/kumuh untuk dialihkan' bagi pembangunan gedung-gedung. Yang memprihatinkan adalah adanya cara-cara paksaan, ganti rugi yang tidak sepadan dan tidak adanya altematif bagi kehidupan mereka yang kena penggusuran. Di sisi lain, pengelolaan kota besar juga tidak memihak kepada golongan ekonomi lemah dan sektor informal. Sangat sulit bagi mereka memperoleh ruang gerak untuk mempertahankan hidupnya, apalagi untuk memperoleh fasilitas. Semakinmerebaknya. pasar-pasarmodem/plaza-plazasementara pasar-pasar tradisional semakin disingkirkan, menunjukkan semakin terpuruknya nasib kaum lemah/miskin di kota-kota.

\section{Biaya pendidikan yang semakịn mahal}

Kiranya sulit disangkal bahwa biaya pendidikan (khususnya pendidikan tinggi) adalah semakin mahal, apalagi bila diukur dengan pendapatan masyarakàt bawah.
Hampir dapat dilihat dengan jelas oleh mata dan hati kita, bahwa yang dapat memasuki bangku kuliah sekarang ini adalah hanya bagi mereka yang mampu saja. Sepertinya semakin tidak ada tempat bagi anak-anak orang miskin ikut mengenyam pendidikan yang dapat mengangkat nasib keluarga mereka di kemudian hari. Apalagi di sekolah/perguruan tinggi swasta. Oleh karenanya, kondisi pendidikan kita, setidaknya ikut menciptakan kesenjangan sosial ekonomi, karena tidak memihak kepada kaum miskin.

\section{Faktor-faktor Mikro}

Sumber daya alam dan infra struktur yang minim

Salah satu faktor paling dominan yang menyebabkan kemiskinan adalah minimnya sumberdaya alam dan infra struktur di suatu daerah/desa. Semakin sempitnya lahan pertanian dibanding dengan jumlah penduduk yang bertambah banyak, merupakan ciriumum dạerah/desadesa miskin di negara kita. Tanpa adanya upaya besar secara makro seperti Landreform, maka sulit kiranya untuk dapat merubah nasib mereka yang hidupnya menggantungkan dari tanah/pertanian. Cara lain misalnya melalui program transmigrasi, maka rasio antara luas lahan dan jumlah penduduk dapat diatur secara wajar. Ciri lain yang menonjol yang membuat desa tertinggal adalah ditandai oleh minimnya infra struktur seperti kondisi jalan, alat transportasi, penerangan dan air bersih. Walaupun di suatu daerah/desa dapat dihasilkan produk-produk pertanian/ lainnya, tetapi karena minimnya infra struktur tsb maḳa produk tsb tidak dapat dipasarkan dengan baik. 
Mobilitas pekerjaan yang terbatas

Faktor lain dari kondisi mikro yang tidak memungkinkan berubahnya nasib orang miskin adalah karena terbatasnya mobilitas lapangan pekerjaan. Hal ini disebabkan oleh tiadanya lapangan pekerjaan șelain pertanian di daerah yang bersangkutan. Atau kalaupun ada, penduduk setempat tidak memiliki ketrampilan/keahlian yang dibutuhkan untukmengisi lapangan pekerjaan tersebut.

\section{Pola hidup yang menggantungkan pada tanah}

Adanya pola hidup dari masyarakat yang secara turun-temurun. menggantungkan hidupnya dari tanah merupakan penomena yang menyebabkan mereka tidak mendapatkan perubahan. Keadaan seperti ini masih adadi masyarakat yang letaknya terisolasi dari masyarakat pedesaan. Mereka sulit untuk beranjak dari kebiasaan/pola hidup tersebut yang menganggap tanah adalah satu-satunya sumber mata pencaharian. Kelangsungan hidup anak-cucu ditentukan oleh tanah warisan. Padahal jumlah mereka semakin banyak, sementara tanahnya terbatas. Sebagai akibatnya hidup mereka semakin tidak berkecukupan dan menjadi miskin.

\section{Bantuan-bantuan yang Dibutuhkan untuk Mengentaskan Kemiskinan di Indonesia}

Dengan mencermati berbagai faktor baik makro dan mikro yang diduga menjadi penyebab kemiskinan seperti diuraikan di atas, maka secara tidak langsung telah memberikan ccuan tentang upaya-upaya apa yang perlu dilakukan guna pengentasan kemiskinan.
Berkaitan dengan itu maka penulis mencoba memberikan altematif pandangan tentang pokok-pokok upaya pengentasan kemiskinan scbagai berikut:

\section{Kebijaksanan Makro}

1. Secara mendasarperlu adanya kesadaran dari semua pihak untuk kembali kepada UUD ' 45 ' (pasal 33) sebagai pangkal tolak tatanan ekonomi yang memenuhi asas kerakyatan dan kcadilan.

2. Dalam menjabarkan kemauan tersebut maka segala kebijaksanaan yang dapat menimbulkan berbagai kesenjangan sosial-ekonomi perlu ditiadakan. Kita perlu melakukan korcksi total atas kebijaksanaan-kebijaksanaan yang kurang sesuai dengan asas kerakyatan.

3. Seiring dengan itu, maka perlu dimantapkan proses demokratisasi di bidang politik sebagai prasarat terciptanya demokrasi ekonomi.

4. Kebodohan merupakan sumber pokok kemiskinan, oleh karenanya perataan untuk memperoleh pendidikan yang layak juga faktor dominan yang perlu diupayakan.

5. Perluasan lapangan pekerjaan terutama yang padat karya melalui industrialisasi akan sangat membantu dalam pengentasan kemiskinan.

6. Pola pembangunan nasional yang bersifat kewilayahan periu mendapat tekanan terutama bagi wilayah-wilayah yang masih tertinggal.

7. Pengelolaan kota hendaknya memperhatikan pula kepentingan - golongan ekonomi lemah șebagai bagian yang tidak terpisahkan dari kehidupan kota. 
8. Perlunya dilaksanakan program landreform yang menjamin pemilikan tanah yang adil bagi seluruh rakyat.

\section{Kebijaksanaan Mikro}

Bantuan-bantuan yang kiranya dapat dipertimbangkan guna pengentasan kemiskinan di daérah, termasuk dalam menunjang Program IDT, antara lain melalui sebagai berikut:

1. Mengarahkan kegiatan pengabdian masyarakat dari Perguruan Tinggi berupa program desa-desa binaan yang masih tertinggal.

2. Ikut menyusun model-model pembangunan desa tertinggal sesuai dengan kondisi setempat.

3. Menyediakan program pengembangan ketrampilan bagi masyarakat yang memiliki potensi tertentu.

4. Memikirkan terciptanya lapangan pekerjaan baru bagi masyarakat desa tertinggal.
5. Memberikan penyuluhan tentangupayaupaya pengembangan mutu produkproduk pertanian/lainnya sehingga memiliki nilai tambah.

6. Membangun prasarana yang dibutuhkan guna memajukan aktivitas ckonomi desa tertinggal.

7. Memberikan kontrol sosial atas pelaksanaan IDT dan menyampaikan saran-saran perbaikan.

8. Menggalakkan terciptanya kegiatankegiatan swadaya masyarakat dalam menambah penghasilan keluarga (seperti Usaha Peningkatan Pendapatan Keluarga Akseptor atau UPPKA, Pengembangan Usaha Terpadu Penanggulangan Kemiskinan atau PUTPK).

9. Mendirikan BPR Syariah dan kelembagaan-kelembagaan lain bagi pengembangan usaha masyarakat desa. 